JurnalEkonomi Pem6angunan Vol. 3, No. 2 (2017) 52-65

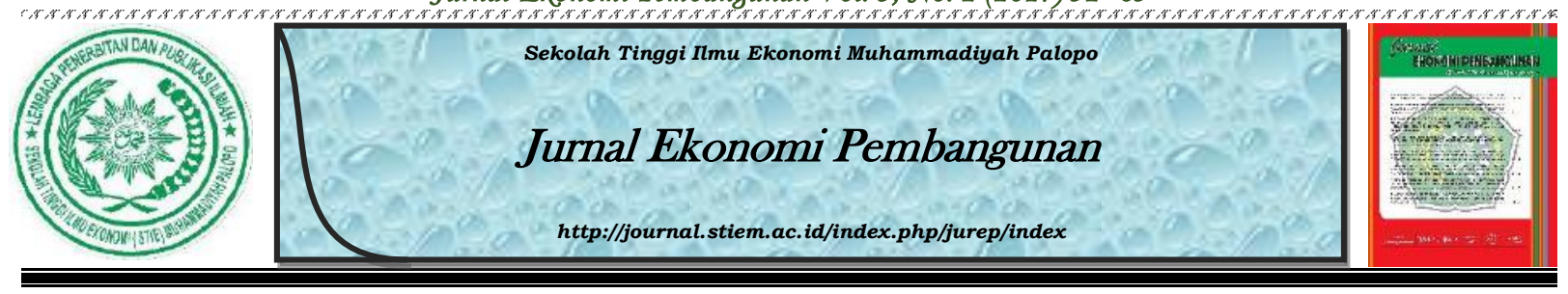

\title{
Analisis Kelembagaan Penerapan Konsep Blue Economy pada Tambak Udang (Studi Kasus di Dusun Ngentak Desa Poncosari Kecamatan Srandakan Kabupaten Bantul)
}

\author{
Lestari Sukarniati $^{1}$, Rifki Khoirudin ${ }^{2}$
}

$\underline{{ }^{1,2} \text { Universitas Ahmad Dahlan Yogyakarta }}$

\section{INFO NASKAH}

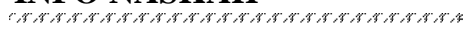
Diserahkan

2 Juli 2017

Diterima

22 Juli 2017

Diterima dalam revisi

6 Desember 2017

Diterima dan disetujui

9 Desember 2017

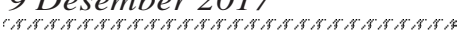

\section{Kata Kunci:}

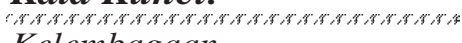

Kelembagaan

Petani udang

Blue economy

Kode Klasifikasi JEL:

O10

012

015

\begin{abstract}
ABSTRAK
Penelitian ini bertujuan untuk mengkaji kondisi kelembagaan tambak udang Vanname yang dilakukan dengan metode ecoshrimp busmetik. Kondisi kelembagaan yang dikaji adalah terkait dengan penerapan konsep blue economy. Penelitian ini dilakukan di wilayah pantai-pantai selatan Desa Poncosari, Kabupaten Bantul, Yogyakarta. Pendekatan yang digunakan dalam penelitian ini adalah pendekatan kualitatif dengan melakukan wawancara secara mendalam terhadap pengurus kelompok tani dan aparat desa setempat. Hasil penelitian menunjukkan bahwa petani tambak belum sepenuhnya mengimplemetasikan (menerapkan) konsep blue economy. Hal ini disebabkan oleh tidak adanya dukungan dari Pemerintah dalam usaha ini. Tidak adanya dukungan tersebut berdampak pada kebutuhan sarana yang tidak terpenuhi. Sehingga penerapan konsep blue economy tidak dapat diterapkan secara penuh. Selain itu sarana pendukung lain yang diperlukan seperti jalan yang memadai juga tidak tersedia.
\end{abstract}

\section{Pendahuluan}

Kebutuhan manusia untuk mencukupi pangan meningkat seiring dengan perkembangan gaya hidup dan jumlah penduduk. Namun di sisi lain ketersediaan sumber daya begitu terbatas. Sehingga menimbulkan ancaman terhadap defisit pemenuhan kebutuhan yang dapat memicu kegiatan eksploitasi sumber daya dan ekologi secara berlebihan. Padahal eksploitasi sumber daya alam yang dilakukan secara berlebihan pada saat ini dapat mengancam keberlanjutan perkembangan ekonomi pada masa yang akan datang. Salah satu sumber daya

\footnotetext{
Corresponding Author:

${ }^{1}$ lestari.sukarniati@ep.uad.ac.id; +62 8562850132

2 rifki.khoirudin@ep.uad.ac.id; +62 81327578462
} 
potensial yang dimiliki Indonesia adalah sumber daya perikanan.

Secara normatif dalam melakukan pengelolaan, perikanan tidak bisa terlepas dari tiga dimensi yakni dimensi perikanan dan ekosistemnya; dimensi pemanfaatan sumber daya perikakanan untuk kepentingan sosial ekonomi masyarakat; dan dimensi kebijakan perekonomian. Selama ini dimensi kedua lebih menonjol dari dimensi yang lain. Ekosistem yang menjadi wadah sumber daya itu sendiri belum diperhatikan sebagai mana mestinya sehingga yang kemudian terjadi adalah eksploitasi terhadap sumber daya tersebut (Kementrian Kelautan, 2013). Oleh karena itu, pendekatan integratif dan inovasi sangat diperlukan untuk keberlanjutan keberadaan sumber daya dalam rangka untuk menyelamatkan ekologi dan menciptakan pertumbuhan ekonomi berkelanjutan.

Pendekatan ekosistem menjadi penting untuk diterapkan. Policy, strategi, dan manajemen operasional memerlukan komitmen dari pemerintah yaitu memerlukan adanya mekanisme koordinasi pengambil kebijakan di tingkat pusat dan daerah, koordinasi antar sektor, dan hubungan antar regulasi yang ada. Rencana strategis paling tidak juga memuat instrumen aturan main dan perangkat pengelolaan input dan output kontrol yang disusun berdasarkan analisis risiko terhadap keberlanjutan sistem perikanan (Cochrane, 2012 dalam Departemen Kelautan 2013).

Berkaitan dengan pengelolaan perikanan melalui pendekatan ekosistem kemudian dikenal istilah blue economy yang berlandaskan pada integrasi tiga pilar yaitu pilar ekosistem, pilar ekonomi, dan sosial. Konsep blue economy mulai dicoba untuk diterapkan di Indonesia pada tahun 2013. Konsep tersebut dianggap layak diterapkan di Indoesia mengingat sebagian besar (67\%) wilayah Indonesia berupa lautan sehingga sumber daya laut yang dimiliki Indonesia juga sangat berlimpah. Penerapan konsep blue economy ini diharapkan mampu menjadi primadona di masa mendatang dengan potensi perikanan dan kelautan Indonesia dan menghasilkan pendapatan negara yang luar biasa (unpad.ac.id, 3/03/2014). Adanya pengelolaan laut berkelanjutan diharapkan dapat meningkatkan perekonomian dan menciptakan kemakmuran masyarakat Indonesia.

(http://www.tribunnews.com/bisnis/2014/08/30/blue-economy-tingkatkan-ekonomi-dalamnegeri-dari-sektor-kelautan).

Bantul merupakan salah satu daerah yang memiliki potensi kelautan dan potensi untuk menerapkan konsep blue economy karena sepanjang pantai selatan wilayah Bantul bertebaran budidaya udang, salah satunya budidaya udang Vanname. Budidaya udang Vanname yang 
menerapkan konsep blue economy menggunakan teknologi yang berbeda dengan teknologi yang biasa dipakai sebelumnya. Teknologi yang digunakan adalah ecoshrimp busmetik. Ecoshrimp busmetik sebagai budidaya udang skala mini tambak plastik yang dikelola dengan menjaga keseimbangan ekosistem tambak yang memperhatikan pemanfaatan lahan tambak, mengelola pembuangan air limbah, menghemat air, menanam mangrove di sekitarnya.

Salah satu daerah penghasil udang Vanname di Yogyakarta adala Desa Poncosari kecamatan srandakan Kabupaten Bantul. Budidaya udang Vanname pada desa ini dilakukan dengan menerapkan metode ecoshrimp busmetik yang dianggap ramah lingkungan dan sesuai dengan konsep blue economy. Oleh karena itu, peneliti memilih kecamatan Srandakan sebagai lokasi penelitian. Implementasi konsep blue economy tentu saja membutuhkan kesiapan kelembagaan agar mendapatkan hasil yang optimal. Acemonglu dan Robinson (dalam Erani, 2012:18) berpendapat bahwa kelembagaan merupakan sumber terpenting yang menentukan perekonomian suatu negara gagal atau maju. Sehingga dalam penerapannya perlu adanya kesiapan kelembagaan yang dapat mempengaruhi keberhasilan konsep tersebut.

Peran kelembagaan dalam pengelolaan suatu usaha perekonomian rakyat perlu dikuatkan untuk menuju pangsa pasar yang lebih luas seperti struktur kepengurusan dengan deskripsi kerja yang jelas sehingga badan usaha yang dibentuk dapat dimaksimalkan fungsinya untuk kemajuan usaha rakyat. Optimalisasi kerjasama sektor kelautan dan perikanan dengan model blue economy dalam APEC juga didukung dalam leaders declaration pada KTT APEC di Bogor, poin ke-8 menyatakan bahwa "membangun dan mempercepat pertumbuhan ekonomi dibutuhkan sumber daya manusia dan alam untuk memperkecil kesenjangan ekonomi”. Sumber daya alam tersebut termasuk potensi ekonomi kelautan, yaitu sektor perikanan.

Asia Pasifik merupakan kawasan produsen ikan terbesar dan rumah terumbu karang terluas di dunia. APEC yang beranggotakan 21 negara telah menyumbang 100 juta ton produksi perikanan dari 141 juta ton produksi perikanan dunia. Maka sudah sepantasnya dalam pemanfaatan sumber daya alam tersebut dilakukan dengan model blue economy agar lingkungan tetap terjaga (Rani dan Cahyasari, 2015).Penerapan cara baru budidaya udang dalam konteks ini daerah Bantul juga perlu kesiapan kelembagaan agar dapat berjalan dengan baik. Penelitian ini bertujuan untuk mengetahui apakah nelayan tambak udang di Dusun Ngentak Desa Poncosari telah menerapkan konsep blue economy; bagaimana kondisi kelembagaannya; mengetahui SWOT dalam dimensi kelembagaan; dan mengetahui kebutuhan pengembangan usaha dalam perspektif kelembagaan. 


\section{Kajian Pustaka}

\section{Pembangunan Berkelanjutan (Sustainability Development)}

Memburuknya lingkungan hidup akibat aktifitas ekonomi yang semakin meningkat perlu segera mendapatkan perhatian. Pembangunan yang berkelanjutan (sustainability development) adalah pertumbuhan ekonomi dan pelestarian lingkungan hidup atau sumber-sumber alam; pemenuhan generasi sekarang tanpa merugikan kebutuhan generasi mendatang (Thodaro, 2003). Pembangunan berkelanjutan tidak mengurangi kemampuan generasi dalam pembangunan, melainkan menjaga fungsi sumber daya alam dan lingkungan yang ada tidak menurun, tanpa digantikan oleh sumber daya lainnya. Pertumbuhan ekonomi pada masa yang akan datang dan kualitas kehidupan umat manusia secara keseluruhan sangar ditentukan oleh kualitas lingkungan hidup yang ada pada saat ini.

\section{Green Economy}

Program lingkungan PBB (UNEP; United Nations Environment Programme) dalam laporannya berjudul Towards Green Economy menjelaskan bahwa ekonomi hijau adalah ekonomi yang mampu meningkatkan kesejahteraan dan keadilan sosial. Ekonomi hijau ingin menghilangkan dampak negatif pertumbuhan ekonomi terhadap lingkungan dan kelangkaan sumber daya alam. (UNEP, 2011). UNEP menyatakan "economy which is low carbon, resource efficient and socially inclusive (UNEP, 2011). Sehingga dapat dikatakan bahwa ada tiga pilar ekonomi hijau menurut UNEP yaitu perekonomian yang rendah karbon/ perekonomian yang tidak menghasilkan emisi dan polusi lingkungan; perekonomian yang menggunakan sumber daya alam secara hemat; dan perekonomian yang memperhatikan masalah keadilan sosial. Ekonomi hijau merupakan motor utama berlangsungnya pembangunan berkelanjutan.

\section{Suistainable Development Goals (SDGs)}

Perserikatan Bangsa-Bangsa (PBB) pada tahun 2015 meluncurkan program pembangunan berkelanjutan yang diberi nama Sustainable Development Goals (SDGs), melanjutkan program sebelumnya Millennium Development Goals (MDGs) yang selesai pada akhir tahun 2015. Tujuan dari Sustainable Development Goals (SDGs) tidak berbeda jauh dari Millennium Development Goals (MDGs) antara lain mengakhiri kemiskinan, menjamin kehidupan sehat, mempromosikan pendidikan, dan memerangi perubahan iklim. Secara umum SDG's memiliki 17 sasaran, di mana sasaran 14 berisikan pelestarian dan pemanfaatan sumber daya samudera, 
laut dan kelautan untuk pembangunan berkelanjutan. Goal 14 SDG's dapat menjadi visi menciptakan Indonesia sebagai poros maritim dunia, tentunya dengan pengelolaan yang lestari dan berkelanjutan. Berikut sasaran-sasaran dalam Goal 14 SDG's (www.kkp.go.id):

a. Pada 2025 dapat mengurangi secara signifikan semua jenis pencemaran laut, terutama yang berasal dari kegiatan di darat, termasuk pembuangan sampah di laut dan polusi nutrisi.

b. Pada 2020 dapat mengelola dan melindungi ekosistem laut dan pesisir secara berkelanjutan untuk menghindari dampak buruk yang signifikan. Termasuk dalam kegiatan ini yaitu dengan memperkuat pertahanan, dan tindakan pemulihkan kondisi untuk mencapai lautan yang sehat dan produktif.

c. Meminimalisir dan mengatasi dampak pengasaman laut melalui peningkatan kerja sama riset dan penelitian ilmiah.

d. Pada 2020 dapat secara efektif mengurangi Illegal Unreported and Unregulated (IUU) fishing, dan over fishing, melalui pembuatan regulasi dan manajemen tata kelola berbasiskan ilmu pengetahuan. Sasarannya adalah mengembalikan stok ikan pada kondisi yang layak dan lestari sesuai dengan karakteristik biologisnya.

e. Pada 2020 dapat menyediakan lahan konservasi laut setidaknya 10 persen dari wilayah pesisir dan perairan yang ada, sesuai dengan hukum nasional dan internasional serta berdasarkan kajian ilmiah yang tersedia.

f. Pada 2020 sudah memiliki instrumen yang dapat melarang kegiatan-kegiatan yang berkontribusi kepada penangkapan berlebih (overfishing), atau IUU fishing seperti bentukbentuk tertentu dari pemberian subsidi perikanan. Khusus negara-negara berkembang dan kurang berkembang yang memerlukan perlakuan khusus perlu ada pengembangan sistem subsdi baru yang menjadi bagian integral dari program WTO.

g. Pada 2030, dapat meningkatkan manfaat ekonomi yang besar bagi negara-negara pulau berkembang dari pemanfaatan sumber daya kelautan, termasuk melalui pengelolaan berkelanjutan perikanan, budidaya, dan pariwisata.

Pengelolaan Perikanan Berpendekatan Ekosistem (Ecosystem Approach to Fisheries Management)

FAO mendefinisikan:

"Ecosystem Approach to Fisheries Managemen is an ecosisstem approach to fisheries strives to balance diverse societal objectives by taking account of knowledge and uncertainties about biotic, abiotic and human components of ecosystem and their 
interaction and applying an integrated approach to fisheries within ecological meaningfull boundaries" (FAO, 2003).

Konsep EAF dapat dipahami sebagai konsep tentang bagaimana menyeimbangkan antara tujuan sosial ekonomi dalam pengelolaan perikanan dengan tetap mempertimbangan pengetahuan, informasi, ketidakpastian komponen biotik, abiotik dan interaksi manusia dalam ekosistem perariran melalui pengelolaan perikanan yang terpadu, komprehensif, dan berkelanjutan. Pengelolaan perikanan berpendekatan ekosistem dilakukan secara integratif dan selayaknya dilakukan oleh semua daerah yang ada. Peningkatan pelestarian ekologi secara menyeluruh, setelah kebijakan yang akan diterapkan pemerintah sudah disahkan maka perlu sebuah dasar untuk memulai pembangunan ekonomi basis perikanan dan kelautan.

Pemerintah dan pelaku pembangunan juga harus memiliki visi dan tujuan yang sama dalam melestarikan sehingga tidak terdapat tumpang tindih yang menyebabkan overcollecting pada satu titik potensi saja. Maka perlu adanya program pengelolaan lingkungan yang terpadu dan bijaksana di setiap kegiatan pembangun. Pemerintah diharapkan memberikan kebijakan yang kondusif dalam pengelolaan lingkungan sedangkan pelaku usaha melakukan promosi serta pembangunan pada sektor informal lainnya yang mengarah pada visi dan orientasi serta tujuan yang sama (Hakim, 2013).

\section{Blue Economy}

Istilah blue economy telah dipakai olah banyak negara dalam pembangunan berbasis lingkungan. Istilah tersebut juga telah diangkat dalam berbagai kerjasama internasional seperti pada pertemuan tingkat senior officials meeting (SOM) for the asia pacific economic cooperation (APEC). Konsep tersebut mengutamakan tiga hal yakni pertumbuhan, kesejahteraan masyarakat, dan penyehatan lingkungan. Blue economy merupakan konsep optimalisasi sumber daya perairan yang bertujuan untuk meningkaktkan pertumbuhan ekonomi melalui berbagai kegiatan yang inovatif dan kreatif dengan tetap menjamin keberlanjutan usaha dan kelestarian lingkungan. Konsep blue economy mengedepankan dan menitikberatkan pada efisiensi yang mendorong adanya pengembangan investasi/bisnis perikanan dengan menjaga lingkungan.

Inti utama dari blue economy ini adalah kegiatan yang proekosistem. Segala limbah keluaran dari kegiatan perikanan harus berada dalam kondisi yang tidak mencemari tanah maupun perairan umum. Limbah kimia maupun limbah organik secara langsung maupun tidak 
langsung akan berpengaruh pada habitat dan kehidupan ekosistem, maka perlu ada ilmu dan teknologi dalam men-treatment keluaran limbah (Ilma, 2014). Blue economy sebagai konsep baru pembangunan kelautan dan perikanan akan diarahkan pada pembangunan ekonomi yang seimbang antara pemanfaatan sumber daya kelautan dan perikanan dengan upaya pengelolaan lingkungan secara optimal dan berkelanjutan (Nurhayati, 2013). Blue economy merupakan rangkaian pendekatan kegiatan ekonomi yang meliputi aktifitas yang ramah lingkungan, berkelanjutan, multi produk, sistem produksi bersiklus, minimum buangan dengan menekankan pada aspek inovasi berwawasan ekosistem-sains dan teknologi, keterlibatan masyarakat melalui transfer pengetahuan, praktek kewirausahaan untuk membangun ekonomi lokal menuju pengetasan kemiskinan (Press Release The $9^{\text {th }}$ World Congress on Blue Economy, Surabaya 13-15 April 2015).

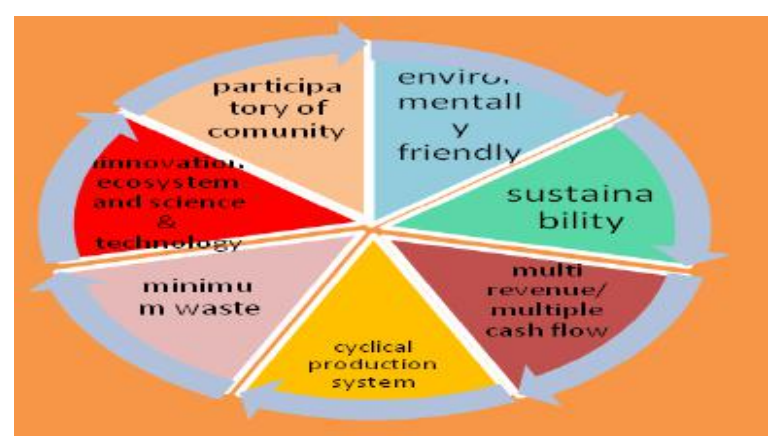

Gambar 1. Prinsip Blue Economy

Konsep ini menganut beberapa prinsip, yaitu kreativitas, inovasi, memanfaatkan sumber daya lokal, dan pemanfaatan material yang diupayakan untuk tidak menyisakan limbah dalam rangka pengelolaan sumber daya alam yang lebih baik. Blue economy mengoptimalkan potensi kelautan yang ada dengan mengedepankan prinsip ekosistem dan berupaya untuk menghasilkan output secara optimal namun tetap memperhatikan lingkungan sekitar (tidak menimbulkan emisi dan pengolahan limbah yang baik).

(www.rieres.com/blueeconomy_555f7f85e9afbdab048b4567; 14 Desember 2015).

Konsep ini bertumpu pada dunia usaha dan sektor industri yang dijalankan secara bersama-sama dengan pemerintah sebagai investor bidang infrastruktur dan pemberi insentif bagi penciptaaan inovasi dalam pengelolaan sumber daya alam yang lebih efisensi dan efektif. Konsep tersebut terintegrasi antara ekonomi dan lingkungan, sistem produksi, dan kebijakan pemerintah. Yang kedua, berbasis kawasan. Ketiga, sistem produksi bersih, efisien tanpa limbah, bebas pencemaran, dan tidak merusak lingkungan. Keempat, investasi kreatif dan inovatif, yakni penanaman modal dan bisnis dengan model blue economy. 
Secara umum tujuan blue economy (Smaragdina, 2015) adalah: (1) improve the natural resources and economic value for the welfare of society; (2) improve the economy activity with the concept of sustainable development; (3) improve the local community acces to the economic resources; (4) encourage of the innovative development and creativity for increase the efficiency and value added of the natural resources; dan (5) to develop the natural resources management system in balance bertween utilization and conservation of the environment.

\section{Hubungan Sustainable Development, Blue Economy dan Green Economy}

Blue economy dan green economy adalah dua konsep yang memperhatikan masalah lingkungan dalam mencapai sustainable development. Blue economy mengoreksi green economy dalam penekanannya pada: (1) bidang nirlimbah (zero waste) dan menekankan sistem siklikal dalam proses produksi sehingga tercipta sistem produksi bersih; (2) inklusi sosial, berarti pemerataan sosial dan kesempatan kerja yang banyak untuk orang miskin; (3) inovasi dan adaptasi yang memperhatikan hukum fisika dan sifat alam adaptif; dan (4) efek ekonomi pengganda, berarti aktivitas ekonomi yang dilakukan akan memiliki dampak luas dan tidak rentan terhadap gejolak pasar, karena blue economy menekankan produk ganda (Arif, 2012). Berikut hubungan dan perbedaan antara green eonomy dan blue economy.

Tabel 1. Green Economy dan Blue economy

\begin{tabular}{|c|c|}
\hline GREEN ECONOMY & BLUE ECONOMY \\
\hline $\begin{array}{l}\text { The principle: reduce carbon, the efficiency of natural } \\
\text { resources, the expert including sociality }\end{array}$ & $\begin{array}{l}\text { The principle: The principles of sustainable the } \\
\text { natural resources management and supported by } \\
\text { clean production system without damage the } \\
\text { environment for the welfare of human today and } \\
\text { the future. Learn from nature }\end{array}$ \\
\hline $\begin{array}{l}\text { The indicators: high investment, low carbon, reduce } \\
\text { wasrw, using limied manpower, linear system. }\end{array}$ & $\begin{array}{l}\text { The indicators : give the entrepreneur the } \\
\text { opportunity, give the advantage for the company } \\
\text { (new economic models) with the clean } \\
\text { environment anfd efficiency, cycle system }\end{array}$ \\
\hline $\begin{array}{c}\text { The Efficiency of natural resources : energy, water, soil, } \\
\text { the ecossystem, change, rubbiss and emmission (B3) }\end{array}$ & $\begin{array}{c}\text { Change the way of thinking by increasing } \\
\text { entrepreneur spirit, more competence, innovation } \\
\text { and creative }\end{array}$ \\
\hline
\end{tabular}

\section{Kelembagaan dalam Pengelolaan Perikanan di Indonesia}

Selama ini orang berpendapat bahwa pertumbuhan dan pembangunan ekonomi hanya dipengaruhi oleh faktor fundamental (akumulasi kapital, teknologi, dan modal manusia). 
Faktor kelembagaan dianggap sebagai sesuatu yang given. Padahal faktor kelembagaan sangat berperan dalam menciptakan hambatan atau perkembangan ekonomi. Kelembagaan dalam konteks sektor perikanan, dapat dimaknai seperangkat aturan yang mempengaruhi bagaimana pemerintah/koperasi/paguyuban petani tambak mengorganisasi untuk menyediakan udang maupun berinteraksi dengan pelaku ekonomi lainnya. Aturan tersebut meliputi peraturan pemerintah, kesepakatan bersama atau norma masyarakat setempat.

Departemen Kelautan dan Perikanan telah menyusun indikator kelembagaan untuk Wilayah Pengelolaan Perikan yang meliputi ada tidaknya: otoritas tunggal pengelolaan perikanan; tingkat sinergitas kebijakan dan kelembagaan; kapasitas pemangku kepentingan; mekanisme pengambilan keputusan; kelengkapan aturan main pengelolaan perikanan; kepatuhan prinsip perikanan bertanggung jawab; konflik perikanan; dan rencana pengelolaan perikanan. Selain indikator kelembagaan ada pula indikator sosial yang meliputi partisipasi pemangku kepentingan; konflik perikanan; dan pemanfaatan pengetahuan lokal.

\section{Teknologi Ecoshrimp-Busmetik}

Blue economy dalam budidaya udang Vanname dilakukan dengan meggunakan teknologi ecoshrimp busmeti. Teknologi ini merupakan teknologi budidaya udang skala mini tambak plastik dengan pendekatan ekologi dengan menjaga keseimbangan ekosistem lingkungan. Penguunaan mulsa/plastik bisa lebih hemat air, kualitas air lebih terjaga. Penggunaan teknologi ini menunjukkan bahwa petani tambak udang sudah menerapkan perspektif pembangunan kelautan dan perikanan berkelanjutan (Smith, 1997). Pembangunan kelautan dengan model ekonomi biru akan ditekankan pada aktivitas yang mengolah seluruh limbah hasil produksi menjadi input bagi produksi aktivitas ekonomi yang lain. Sehingga kegiatan ekonomi kelautan dan perikanan harus diarahkan menjadi suatu sistem siklus produksi yang berkelanjutan dan tentu prinsip inovasi dan kreativitas menjadi sangat penting dan dibutuhkan. (Rani dan Cahyasari, 2015).

\section{Metode Penelitian}

\subsection{Pendekatan Penelitian}

Penelitian ini menganalisis kelembagaan penerapan konsep blue economy pada tambak udang. Penelitian ini dilakukan dengan pendekatan kualitatif. Data yang dipakai dalam penelitian ini adalah data sekunder dan data primer. Data sekunder diperoleh dari Dinas 
Perikanan Kabupaten Bantul. Data primer diperoleh dengan cara wawancara mendalam menggunakan panduan kuesioner kepada pengurus kelompok tani dan aparat desa. Metode pengambilan sampelnya adalah purposive sampling. Metode pengambilan sampel ini dipilih karena memang peneliti hanya ingin mewawancarai orang yang benar-benar mengetahui permasalahan secara mendalam.

\subsection{Metode Analisis Data}

Metode analsis yang digunakan adalah analisis SWOT (Jogiyanto, 2014; Freddy, 2014). Analisis SWOT berupaya memperoleh informasi tentang kekuatan, kelemahan, peluang dan ancaman budidaya udang Vanname di Desa Poncosari. Analisis ini didasarkan pada logika yang dapat memaksimalkan kekuatan dan peluang. Namun secara bersamaan dapat meminimalkan kelemahan dan ancaman. Analisis SWOT mempertimbangkan faktor lingkungan eksternal peluang dan ancaman yang dihadapi dunia bisnis serta lingkungan internal kekuatan dan kelemahan. Selain itu, analasis SWOT membandingkan antara faktor eksternal peluang dan ancaman dengan faktor internal kekuatan dan kelemahan sehingga dari analisis tersebut dapat diambil suatu keputusan strategis suatu organisasi.

\section{Hasil dan Pembahasan}

\section{Keberadaan Tambak Udang Vanname di Desa Poncosari}

Tambak udang Vanname di Desa Poncosari mulai beroperasi pada bulan April 2013. Budidaya udang yang dilakukan berada di lokasi yang sebelumnya berupa lahan tidur milik Sultan dan Kas desa. Ide untuk melakukan usaha tambak datang dari beberapa warga (Bapak Suyanto dan Bapak Kholil) yang sebelumnya melihat keberhasilan tambak udang Vanname di daerah Jawa Barat dan bertemu dengan Bapak Budi yang sebelumnya sudah punya pengalaman bekerja di perusahaan udang Vanname. Awal dilakukan budidaya udang, petani menikmati keuntungan yang besar, harga jual rata-rata udang Vanname sekitar Rp45.000Rp80.000 perkilogram tergantung pada besar kecilnya udang. Sekali panen seorang petani dapat memperoleh keuntungan bersih sebesar Rp60 juta dengan luas rata-rata kolam $1.500 \mathrm{~m}^{2}$ dan dapat panen sebanyak 3 kali.

Panen pertama ke panen selanjutnya keuntungan petani semakin menurun karena adanya penyakit yang menyerang udang disebabkan oleh pengotoran tambak (limbah pakan). Tahun berikutnya (tahun 2014) jumlah petani menurun karena semakin besarnya biaya produksi dan 
semakin menipisnya keuntungan, hingga pada tahun 2015 jumlah petani tambak tinggal sebanyak 32 orang. Akibatnya nelayan tidak lagi aktif dan tidak pernah menyelenggarakan pertemuan yang sebelumnya dilaksanakan secara rutin sebulan sekali.

Tabel 2. Analisis Implementasi Blue Economy

\begin{tabular}{|c|l|l|l|}
\hline No & Aspek Blue Economy & Temuan Lapangan & Keterangan \\
\hline 1 & Masyarakat & Inisiatif, Mandiri & \\
\hline 2 & Lingkungan & Kebersihan kurang & Limbah belum dimanfaatkan \\
\hline 3 & Keberlanjutan & Naik turunnya biaya & \\
\hline 4 & Multiple cash flow & Cash flow hanya dari udang & Pemanfaatan limbah \\
\hline 5 & Cyclical production system & Produksi tiga kali setahun & Cara pembudidayaan \\
\hline 6 & Minimalitasi limbah & Pengelolaan limbah belum ada & \\
\hline
\end{tabular}

Sumber: hasil penelitian 2016

Tabel di atas menunjukkan bahwa dari enam aspek blue economy, yang terpenuhi hanya aspek partisipasi masyarakat karena kegiatan ini sepenuhnya dilakukan oleh masyarakat. Aspek yang lain tidak terpenuhi karena kegiatan tersebut menghasilkan limbah yang mencemari lingkungan. Aspek keberlanjutan tidak terbukti karena semakin berkurangnya jumlah petani tambak. Kegiatan tambak udang yang ada juga tidak memiliki multiple cash flow, tidak ada usaha lain yang muncul yang ada kaitannya dengan tambak udang tersebut. Walaupun budidaya udang dilakukan dengan plastik (ecoshrimp busmetik), tapi belum memenuhi syarat menerapkan konsep blue economy.

\section{Analisis Aspek Kelembagaan}

Penerapan aspek kelembagaan dalam konsep blue economy dalam penelitian ini perlu adanya pembinaaan dan pengawasan dari dinas terkait untuk keberlangsungan usaha petani tambak udang Vaname. Pelatihan tersebut sebaiknya dilakukan secara terus menerus dikarenakan permasalahan yang dihadapi oleh petani tambak udang bisa bervariasi dari waktu ke waktu. Apalagi dengan modal yang tidak sedikit, usaha jenis ini mengandung risiko yang tinggi untuk gagal panen. Hasil penelitian memperlihatkan bahwa dari delapan indikator kelembagaan dalam pengelolaan perikanan, sisi kelembagaan dalam budidaya udang Vanname tidak memenuhi syarat sehingga dapat dikatakan bahwa kelembagaan yang ada tidak mendukung keberadaan tambak udang Vanname di Desa Poncosari. Hal itu berdampak pada minimnya infrastruktur pendukung tambak udang seperti instalasi pengolahan limbah, jalan yang memadai, dan tidak adanya dukungan dari pemerintah baik dari kelurahan, dinas 
perikanan kabupaten maupun propinsi.

Berdasarkan hasil wawancara, pada waktu nelayan kesulitan untuk mendapatkan bahan bakar untuk mengoperasikan kincir angin, pemerintah juga tidak membantu. Optimalisasi budidaya udang Vanname seharusnya memperhatikan tambak dalam keadaan bebas hama. Jika salah satu lokasi terkena hama akan mudah menyebar lewat udara yang bergerak karena adanya kincir angin di setiap tambak yang sebenarnya fungsi kincir angin adalah menyediakan pasokan oksigen untuk tambak.

Munculnya hama penyakit menyebabkan munculnya obat pembasmi hama yang berarti meningkatkan biaya produksi. Menumpuknya limbah pakan menyebabkan penyakit dan biaya semakin meningkat untuk menanggulanginya. Sehingga secara keseluruhan biaya produksi semakin meningkat, margin keuntungan semakin menurun Adanya peningkatan resiko akibat kotornya lingkungan menyebabkan sebagian petani berhenti melakukan aktifitasnya. Hasil wawancara mendalam dengan responden mengenai aspek kelembagaannya dapat disusun analisis SWOT kelembagaan sebagai berikut:

Tabel 3. Analisis Implementasi Blue Economy

\begin{tabular}{|c|c|}
\hline S (Kekuatan) & W (Kelemahan) \\
\hline $\begin{array}{l}\text { 1. Sikap bekerja sama yang baik antar anggota } \\
\text { kelompok tani } \\
\text { 2. Sebagian aparat kelurahan ada yang pernah } \\
\text { terlibat usaha udang, sebagian yang lain } \\
\text { pernah terlibat dalam usaha tambak udang }\end{array}$ & $\begin{array}{l}\text { 1. Tidak ada campur tangan pemerintah (Tidak ada } \\
\text { kebijakan pemerintah, Tidak ada komunikasi antar } \\
\text { petani dengan pemerintah, tidak ada komunikasi antar } \\
\text { dinas teknis dan kelurahan) } \\
\text { 2. Tidak terdapat mekanisme pengambilan keputusan } \\
\text { 3. Tidak terdapat atauran main } \\
\text { 4. Tidak melakukan pengolahan limbah } \\
\text { 5. Pernak terjadi konflik antara pemerintah dan petani } \\
\text { 6. Tidak Terdapat Rencana pengelolaan perikanan }\end{array}$ \\
\hline O (Peluang) & T (Ancaman) \\
\hline 1. Kelompok tani masih eksis & $\begin{array}{l}\text { 1. Potensi konflik antara pemda dengan petani terkait } \\
\text { dengan tata ruang } \\
\text { 2. Penataan tata ruang }\end{array}$ \\
\hline
\end{tabular}

\section{Simpulan dan Saran}

Berdasarkan analisis yang telah dilakukan pada bab sebelumnya, maka kesimpulan dari penelitian ini sebagai berikut: (1) dilihat dari indikator kelembagaan dalam pengelolaan perikanan, sisi kelembagaan dalam budidaya udang Vanname di Dusun Ngentak, Desa Poncosari tidak memenuhi syarat digolongkan sebagai aktifitas yang menerapkan konsep blue economy; (3) kondisi kelembagaan yang ada tidak mendukung perkembangan budidaya tambak udang di Dusun Ngentak, Desa Poncosari, Kabupaten Bantul. 
Masalah kelembagaan berupa tidak adanya dukungan dari pemerintah baik kelurahan, Dinas perikanan kabupaten maupun Propinsi menyebabkan permasalahan dalam infrastruktur. Udang membutuhkan lingkungan yang bersih agar tidak timbul penyakit. Tidak adanya perhatian dari pemerintah menyebabkan lokasi tambak sama sekali tidak memiliki instalasi pengolahan limbah. Sehingga air bersih bercampur dengan air kotor dan menimbulkan penyakit pada udang. Selain itu sarana pendukung lain yang diperlukan seperti jalan yang memadai juga tidak tersedia.

Adapun saran yang dapat diberikan dari studi ini adalah: (1) untuk mendukung terciptanya penerapan dari blue economy khususnya di tambak udang yang berada di Desa Poncosari, Srandakan, Bantul diperlukan dukungan dari lembaga terkait dalam hal ini kelurahan, kecamatan, Dinas Perikanan Kabupaten, dan propinsi dalam mengadakan fasilitas laboratorium pengukuran indeks keasaman air. Sehingga pencemaran lingkungan akan lebih dapat diminimalisasi; dan (2) perlu diadakannya penyuluhan tentang bagaimana budidaya udang Vanname sehingga produktifitas dapat ditingkatkan yang pada akhirnya akan meningkatkan kesejahteraan masyarakat.

\section{Daftar Pustaka}

Adam, L. 2016. Pengaruh Konsep Blue Economy Terhadap Broduksi Tambak Udang Vanname di Desa Poncosari Kecamatan Srandakan Kabupaten Bantul Yogyakarta. Yogyakarta: Universitas Ahmad Dahlan.

BPS Kabupaten Bantul. 2014. Bantul dalam Angka.

Erani, A. 2012. Ekonomi Kelembagaan. Jakarta: Salemba Empat.

Hakim, M.F. 2013. Blue Economy Daerah Pesisir Berbasis Kelautan dan Perikanan. Economics Development Analysis Journal, 2 (2): 1-7.

http://www.rieres.com/blueeconomy_555f7f85e9afbdab048b4567. Diakses tanggal 2 Juli 2016.

http://www.tribunnews.com/bisnis/2014/08/30/blue-economy-tingkatkan ekonomi-dalamnegeri-dari-sektor-kelautan. Diakses tanggal 23 Juni 2016.

Ilma, A.F.N. 2014. Blue Economy: Keseimbangan Perspektif Ekonomi dan Lingkungan. Jurnal Ilmu Ekonomi dan Pembangunan, 14 (1): 1-9.

Misuari, M.N., A.N. Bambang, dan Purwanto 2015. Blue Economy Application to Suistainable Fishery Development at the School of Senior Fishery Business Tegal. Jurnal Perikanan, 17 (1): 35-47. 
Nurhayati, S. 2013. Blue and Economy Policy and Their Impact To Indonesian Community Welfare. Jurnal Ekonomi dan Bisnis, 12 (1): 37-42.

Pauli, G. 2010. The Blue Economy 10 Years 100 Innovations 100 Million Jobs. New Mexico: Paradigm Pulications.

Press Release The $9^{\text {th }}$ World Congress on Blue Economy, Surabaya 13-15 April 2015.

Rani, F. dan W. Cahyasari. 2015. Motivasi Indonesia Dalam Menerapkan Model Kebijakan Blue Economy Masa Pemerintahan Joko Widodo. Jurnal Transnasional, 7 (1): 19141928.

Republik Indonesia. 2013. Pendekatan Ekosistem dalam Pengelolaan Perikanan Indonesia.

Republik Indonesia. 2013. Penilaian Indikator untuk Pengelolaan Perikanan Berpendekatan Ekosistem.

Republik Indonesia. Undang-Undang Nomor 32 tahun 2009 tentang Perlindungan dan Pengelolaan Lingkungan Hidup.

Smaragdina, D. 2015. Introduction of Blue Economy. Jakarta: Universitas Indonesia.

Soedomo, S. 2010. Ekonomi Hijau: Pendekatan Sosial, Kultural dan Teknologi. Jakarta: BAPPENAS. 